\title{
The response of climbing bean to fertilizer and organic manure in the Northern Province of Rwanda
}

\author{
Edouard Rurangwa $^{1,3, *}$ (D), Bernard Vanlauwe ${ }^{2}$ and Ken E. Giller ${ }^{3}$ \\ ${ }^{1}$ Rwanda Agriculture and Animal Resources Development Board, KK 18 Ave, B.P 5016 Kigali, Rwanda, ${ }^{2}$ Natural Resource \\ Management Research Area, IITA, c/o ICIPE, Off Thika Highway, Kasarani, PO 30772, Nairobi 00100, Kenya and ${ }^{3}$ Plant \\ Production Systems, Wageningen University, P.O. Box 430, 6700 AK Wageningen, The Netherlands \\ ${ }^{*}$ Corresponding author. Email: edouard.rurangwa1@gmail.com
}

(Received 13 September 2019; revised 10 July 2020; accepted 14 September 2020; first published online 30 October 2020)

\begin{abstract}
Climbing beans play a central role in food security of rural households in the densely populated highlands of East and Central Africa. Soil fertility degradation and the lack of nutrient inputs are major limitations to yield of beans and other crops. We conducted field trials in Northern Rwanda in Kinoni and Muko villages to evaluate the effect of mineral $\mathrm{N}, \mathrm{P}$, and $\mathrm{K}$ fertilizers (both alone and in combination) and farmyard manure on nitrogen fixation and grain yields of climbing bean in smallholder farmers' fields. The trials were laid down in a randomized complete block design with seven replicate blocks in each village. Manure and fertilizer application led to greater yields in all fields, and the largest yields were achieved when manure was combined with NPK. Large variability in yield between fields was observed. Application of fertilizer together with manure increased the grain yield from 1.5 to $3.9 \mathrm{tha}^{-1}$ in Kinoni and from 2.6 to $5.4 \mathrm{tha}^{-1}$ in Muko. Fertilizer and/or manure increased stover yield from 0.8 to $2.3 \mathrm{t} \mathrm{ha}^{-1}$ in Kinoni and from 1.5 to $3.4 \mathrm{tha}^{-1}$ in Muko. Application of $30 \mathrm{~kg} \mathrm{P} \mathrm{ha}^{-1}$ and $5 \mathrm{t}_{\text {manure ha }}{ }^{-1}$ led to increased $\mathrm{N}$ and $\mathrm{P}$ uptake (from 49 to $106 \mathrm{~kg} \mathrm{~N} \mathrm{ha}^{-1}$ and from 6.1 to $12.4 \mathrm{~kg} \mathrm{Pha}^{-1}$ in Kinoni and from 46 to $128 \mathrm{~kg} \mathrm{~N} \mathrm{ha}^{-1}$ and from 5.3 to $17.9 \mathrm{~kg} \mathrm{Pha}^{-1}$ in Muko). There was no clear relationship between soil fertility characteristics and the response of climbing bean to applied inputs at Muko site. However, at Kinoni site, limited response to manure and NPK application was observed in plots where soil available P and soil exchangeable K were relatively low. Our results show the benefits of using manure along with mineral fertilizers for increased climbing bean yields and nutrient uptake in smallholder farming systems.
\end{abstract}

Keywords: Phaseolus vulgaris; Nitrogen fixation; ${ }^{15} \mathrm{~N}$ natural abundance; Nutrients uptake

\section{Introduction}

In densely populated areas of sub-Saharan Africa, nutrient availability is a major limitation to crop growth, since soil fertility regeneration through fallowing land is no longer possible. There is an urgent need to improve agricultural productivity as landholdings have reduced in area due to population growth. To feed the rapidly growing population, sustainable intensification of agricultural production is needed (Vanlauwe et al., 2014), and integrating legumes is key to achieve this goal. Legumes are important crops both for supply of food and fodder and for soil improvement. Legumes fix atmospheric $\mathrm{N}_{2}$ through symbiosis with rhizobia and contribute $\mathrm{N}$ to the soil for use by other crops (Franke et al., 2018). The use of legumes in rotation may lead to a reduction in fertilizer- $\mathrm{N}$ use, reduced pest and weed occurrence, and improved soil quality (Giller, 2001).

Despite the low yields achieved by farmers, common bean (Phaseolus vulgaris L.) remains a major crop in Eastern and Southern Africa (Wortmann et al., 2001). Bush bean varieties have 
been under cultivation since the introduction of common bean in the 16th century, while climbing bean varieties were only found in a few locations and on small plots. The introduction of improved climbing bean varieties in Rwanda resulted in their rapid spread, also into neighboring countries (Sperling and Muyaneza, 1995). Climbing beans are reported to be less constrained by diseases and much more productive than bush bean (Wortmann et al., 2001), as well as being less prone to root rots (Sperling and Muyaneza, 1995). Climbing beans can produce grain yields nearly threefold the yield of bush beans and grow vertically, making climbing bean a crop with great potential in densely populated areas (Musoni et al., 2014).

The indeterminate growth of climbing beans allows them to provide a continuous supply of green leaves and pods as well as dry grain throughout the growing season (Sperling and Muyaneza, 1995; Wortmann et al., 2001). Strong residual effects have been reported when maize is grown after climbing bean, which are attributed to the large amounts of above- and belowground crop residues (Niyuhire et al., 2017), changes in microbial activities (Turco et al., 1990), and access to more P (Bainville et al., 2005). Climbing beans also provide valuable residues for livestock feed. Improved soil cover from climbing beans helps in suppressing weed growth as well as reduces water and soil loss from the steep slopes observed in the Eastern African highlands (Wortmann et al., 2001). However, availability of staking material, the increased labor requirements for staking, and the longer growing period are identified by farmers as disadvantages of climbing bean.

The Northern Province of Rwanda has a very high population density estimated at 528 persons $\mathrm{km}^{-2}$ (NIS, 2012). This has resulted in small landholdings which are continuously cropped resulting in small yields. In this region, up to $95 \%$ of the households grow climbing beans (Franke and deWolf, 2011). Smallholder farmers largely grow legumes with little or no fertilizer, as most mineral or organic fertilizer is targeted to cash crops (e.g. tomato, vegetables, and Irish potato) that have a ready market. Only $12-21 \%$ of the farmers in Northern Province of Rwanda use mineral fertilizer in climbing bean fields (Franke and deWolf, 2011).

Many studies have shown the need for balanced fertilization in soils that have been cropped continuously (Zingore et al., 2008a, 2008b). Integrated soil fertility management has been adopted as a framework for boosting crop productivity (Vanlauwe et al., 2010). One of the best options of addressing soil fertility declines and increasing fertilizer use efficiency is the combined application of organic and mineral fertilizers. A previous study in Northern Province of Rwanda showed that the inherent soil fertility characteristics affected the impact of applied nutrient inputs on the productivity of climbing bean (Franke et al., 2019). There is limited information on the integrated use of farmyard manure and mineral fertilizers on the performance of climbing bean in Rwanda.

The specific objectives of this study were to: (i) evaluate the effect of mineral N, P, and K fertilizers (both alone and in combination) and manure on yields of climbing bean in two sites (seven fields in each) in Northern Rwanda; (ii) assess the effect of mineral P fertilizer and manure on nitrogen fixation, $\mathrm{N}$ and $\mathrm{P}$ uptake; and (iii) explore the influence of soil fertility characteristics on the response of climbing bean to applied nutrients.

\section{Materials and Methods}

\section{Study sites, soil sampling, and field selection}

The experiments were conducted in farmers' fields in Kinoni and Muko villages in the Northern Province of Rwanda. Locations (villages) with low and high potential for cultivation of climbing beans were selected based on soil fertility status and elevation. The color of the soil, soil drainage, soil depth, and crop performance over previous years were the selection criteria used by the farmers from each village. In addition to the soil fertility information, the size of the fields was also among the criteria as many farmers could not get the desired field size. In each village, fields with comparable fertility status, size, and not located in areas potential for water-logging were selected. In each village, seven fields (blocks) were selected. The soils in Muko and Kinoni are classified as 


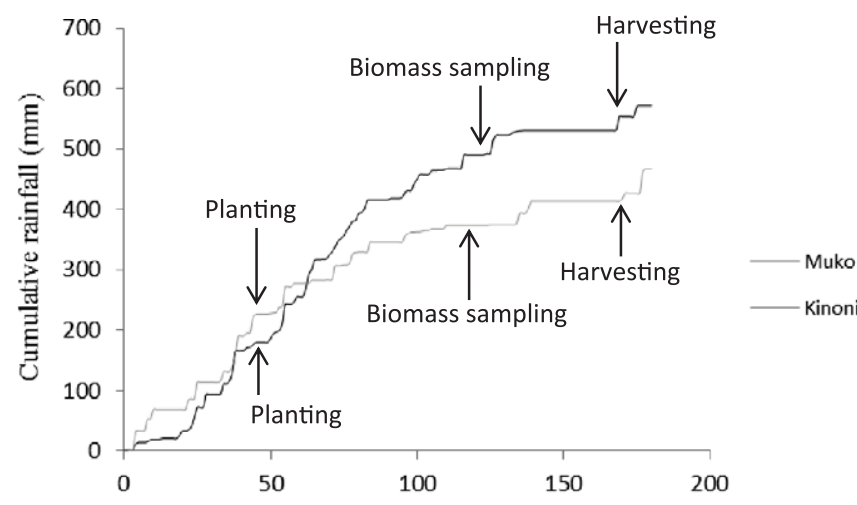

Days from February 1,2014 to July 31,2014
Figure 1. Cumulative rainfall during the experimental period at the Kinoni and Muko sites.

Andosols in the World Reference Base for Soil Resources (FAO, International Soil Reference and Information Centre and International Society of Soil Science).

The information received from farmers of both villages on climbing bean performance over years coupled with their differences in elevation allowed to classify fields in Muko as high potential and those in Kinoni as low potential. The fields in Muko were located in the volcanic plains of Musanze district, with soils having dark color, deep and better water drainage, good history for crop performance (according to farmers), and less prone to erosion. The fields in Kinoni were located on steep slopes on the side of the hills which expose them to erosion that may affect soil fertility over time and plant performance (Rugazura et al., 2015). Kinoni village is located in Burera district at $1^{\circ} 28^{\prime} 26.3^{\prime \prime} \mathrm{S}$ and $29^{\circ} 50^{\prime} 4.8^{\prime \prime} \mathrm{E}$ at an elevation of $2182 \mathrm{~m}$ above sea level (masl), with a mean annual rainfall of $1500 \mathrm{~mm}$ and a mean annual temperature of $21^{\circ} \mathrm{C}$. Muko village is located in Musanze district at $1^{\circ} 30^{\prime} 27.5^{\prime \prime} \mathrm{S}$ and $29^{\circ} 36^{\prime} 23.8^{\prime \prime} \mathrm{E}$ at an elevation of 1850 masl, with a mean annual rainfall of $1400 \mathrm{~mm}$ and a mean annual temperature of $17.8^{\circ} \mathrm{C}$. In addition to the farmers' classification, soils were sampled from each field (block) at a depth of $0-20 \mathrm{~cm}$ from nine points following a $\mathrm{W}$ pattern. The nine samples were thoroughly mixed and a composite sample was taken, air-dried, and passed through a $2 \mathrm{~mm}$ sieve, and then it was taken to the laboratory at Crop Nutrition Laboratory Services in Nairobi, Kenya and analyzed for $\mathrm{pH}\left(\mathrm{H}_{2} \mathrm{O}\right)$, total N, available $\mathrm{P}$ (Olsen), organic $\mathrm{C}$, effective cation exchange capacity, exchangeable cations ( $\mathrm{K}, \mathrm{Ca}, \mathrm{Mg}$, and $\mathrm{Na}$ ), and texture using standard methods (Okalebo et al., 2002). Rainfall distribution and sowing dates are shown in Figure 1.

\section{Trial establishment}

The trials were established in the long rainy season of 2014. Climbing bean variety RWV 1129 was planted at $50 \mathrm{~cm}$ inter-row and $20 \mathrm{~cm}$ intra-row spacing, with three seeds per planting hole and thinned to two at first weeding. It was a factorial experiment with sites at two levels, manure at three rates, and inorganic fertilizer at five rates $(2 \times 3 \times 5)$, laid down in a randomized complete block design with seven replicates (blocks) in each village. The farmyard manure was obtained from the participating farmers and applied to her/his own field at 0 (control), 2, and $5 \mathrm{tha}^{-1}$ of dry weight, mineral fertilizer treatments: none (no fertilizer), $+\mathrm{N},+\mathrm{P},+\mathrm{K}$, and $+\mathrm{NPK}$. $\mathrm{P}$ was applied in the form of TSP at a rate of $30 \mathrm{~kg} \mathrm{Pha}^{-1}$; $\mathrm{K}$ was applied as $\mathrm{KCl}$ at $30 \mathrm{~kg} \mathrm{~K} \mathrm{ha}^{-1}$; and $\mathrm{N}$ was applied as urea, split $50-50$ at sowing and at first weeding (3 weeks after planting), and applied at a rate of $60 \mathrm{~kg} \mathrm{~N} \mathrm{ha}^{-1}$ and NPK as a combination of $\mathrm{N}\left(60 \mathrm{~kg} \mathrm{~N} \mathrm{ha}^{-1}\right.$ as urea applied as in the sole $\mathrm{N}$ treatment), $\mathrm{P}\left(30 \mathrm{~kg} \mathrm{Pha}^{-1}\right.$ as TSP), and $\mathrm{K}\left(30 \mathrm{~kg} \mathrm{Kha}^{-1}\right.$ as $\left.\mathrm{KCl}\right)$. With the rates of 2 and $5 \mathrm{tha}^{-1}$ of manure, each plot received 3.6 and $9.0 \mathrm{~kg}$ of manure, respectively, and was applied 
Figure 2. Relationship between $\mathrm{C}: \mathrm{N}$ ratio and $\mathrm{N}$ applied through manure $\left(\mathrm{kg} \mathrm{ha}^{-1}\right)$ at Kinoni and Muko sites. $2 \mathrm{M}-\mathrm{K}, 2 \mathrm{M}-\mathrm{M}, 5 \mathrm{M}-\mathrm{K}$, and $5 \mathrm{M}-\mathrm{M}$ represent 2 and $5 \mathrm{t}$ of manure $\mathrm{ha}^{-1}$ at Kinoni $(\mathrm{K})$ and Muko (M) sites.

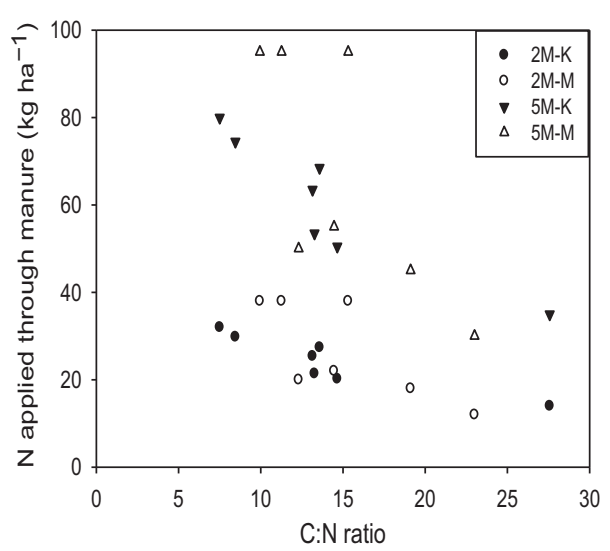

in the planting rows at sowing. Plot size was $4.5 \mathrm{~m} \times 4 \mathrm{~m}$ with final harvest area of $8.75 \mathrm{~m}^{2}$ and a net area for biomass sampling of $1.75 \mathrm{~m}^{2}$. Each field was treated as a single complete replicate (block) and included all the treatments. Adjacent to each replicate (block), a plot $(4.5 \mathrm{~m} \times 4 \mathrm{~m})$ was sown with maize to serve as reference plant for measurement of $\mathrm{N}_{2}$-fixation. The reference plant was planted at the same time as climbing bean. Weeds were regularly controlled using a hand hoe by the farmers when needed. Figure 2 shows the relationship between $\mathrm{N}$ applied through manure and its $\mathrm{C}: \mathrm{N}$ ratio, indicating the variation in manure quality used in the trials.

\section{Yield assessment}

Above ground biomass was determined at late pod-filling stage. A subplot of $1.75 \mathrm{~m}^{2}$ (leaving $0.5 \mathrm{~m}$ away from the plot border) was sampled, all plants were cut at ground level, and fresh weight was determined in the field. A subsample was taken and weighed, sun-dried, and then oven dried at $65^{\circ} \mathrm{C}$ to constant weight to determine the dry matter contents. Final grain and stover yields were determined at crop maturity. All pods were harvested in the net plots excluding the outer rows of both sides of the plot, and the total fresh weight was determined. A subsample was taken, weighed, and sun-dried for several days and then threshed by hand. Grains were cleaned by winnowing and subsequently weighed, and the moisture content was determined using an electronic moisture meter. The grain yield was calculated at $12.5 \%$ moisture. The haulms were harvested by cutting at ground level and weighed. Representative subsamples of haulms from each plot were taken sun-dried, then oven dried at $65^{\circ} \mathrm{C}$ to constant weight, and the dry weight was recorded. Stover yield and biomass yield at late pod-filling were calculated at $0 \%$ moisture.

\section{Assessment of $\mathbf{N}$ and $\mathrm{P}$ uptake and $\mathrm{N}_{\mathbf{2}}$-fixation}

Dry climbing bean biomass was ground and digested in hot $\mathrm{H}_{2} \mathrm{SO}_{4}$ and $\mathrm{H}_{2} \mathrm{O}_{2}$ (Parkinson and Allen, 1975). $\mathrm{N}$ and $\mathrm{P}$ concentrations in the digests were determined by colorimetric methods (Okalebo et al., 1993). The proportion plant $\mathrm{N}$ from $\mathrm{N}_{2}$-fixation was measured using the ${ }^{15} \mathrm{~N}$ natural abundance method (Unkovich et al., 2008). After drying and grinding the samples, ${ }^{15} \mathrm{~N}$ content was determined using a stable isotope mass spectrometer (Thermo Scientific, Delta V Advantage Isotope Ratio MS Coupled through Conflo IV to Thermo Scientific Flash $\mathrm{HT} / \mathrm{EA}, \mathrm{KU}$ Leuven). The $\delta^{15} \mathrm{~N}$ value and the proportion of $\mathrm{N}$ derived from atmosphere 
(\%Ndfa) were calculated. The \% Ndfa (Equation 1) and amount of $\mathrm{N}_{2}$-fixed (Equation 2) were calculated as follows (Unkovich et al., 2008):

$$
\% \mathrm{Ndfa}=\left(\delta^{15} \mathrm{Nref}-\delta^{15} \mathrm{Nleg}\right) /\left(\delta^{15} \mathrm{Nref}-B\right) \times 100
$$

where $\delta^{15} \mathrm{~N}$ ref and $\delta^{15} \mathrm{~N}$ leg are the ${ }^{15} \mathrm{~N}$ natural abundance (\%o) in the non-fixing reference crops (maize) and the fixing species (climbing bean), respectively. The smallest value of $\delta^{15} \mathrm{~N}$ for climbing bean was used as the $B$-value (Peoples et al., 2002) and in this case was $-1.7 \%$.

$$
\text { Amount of } \mathrm{N} \text { fixed }\left[\mathrm{kg} \mathrm{ha}^{-1}\right]=\left(\% \mathrm{Ndfa} \times \text { Total } \mathrm{N} \text { legume }\left[\mathrm{kg} \mathrm{ha}^{-1}\right]\right) / 100
$$

where $\% \mathrm{Ndfa}$ is the percentage of $\mathrm{N}$ from $\mathrm{N}_{2}$-fixation; total $\mathrm{N}$ legume is the product of the $\% \mathrm{~N}$ in the legume plant and the dry biomass yield of the legume plant divided by 100 . The total amount of $\mathrm{N}$ fixed was calculated to include the $\mathrm{N}$ content in the below ground parts, estimated at $30 \%$ of the amount of $\mathrm{N}_{2}$-fixed in the shoots (Unkovich et al., 2008). Shoot $\mathrm{N}$ and $\mathrm{P}$ uptake were determined at late pod-filling.

\section{Data analysis}

Statistical analysis was performed using GenStat (version 16, VSN International Ltd). A mixed effects linear model was used for data analysis with sites $\times$ fertilizer $\times$ manure as fixed factors. Fields (blocks) were nested under sites and included in the model as random factors to account for their effects on grain, biomass, and stover yields. Furthermore, $\mathrm{N}$ and $\mathrm{P}$ uptake and $\mathrm{N}_{2}$-fixation were analyzed at fertilizer $\times$ manure level since there were no significant differences when site was included as fixed factor. Treatment means were compared using the standard error of differences between means at $p \leq 0.05$ significance level.

\section{Results}

\section{Soil and manure characteristics}

Soil and manure characteristics differed within each site and between the sites, though overall differences between the two sites were not significant (Tables 1 and 2). Soil pH was slightly acid to near neutral. Mean soil available $\mathrm{P}$ was above the critical value of $10 \mathrm{mg} \mathrm{P} \mathrm{kg}^{-1}$, but $\mathrm{P}$ availability varied within and across sites. In Kinoni, four out of seven fields had available P concentrations far below the critical value. In Muko, soils had larger concentrations of available P with only two out of seven fields with available $\mathrm{P}$ below the critical value. The soil organic carbon in the two sites was above the reported critical value of $1.5 \%$ in all fields. Exchangeable cations were above the critical values of 0.2 for $\mathrm{Mg}$ in all fields and $\mathrm{K}$ was sufficient $\left(>0.2 \mathrm{cmol}_{\mathrm{c}} \mathrm{kg}^{-1}\right)$ in 9 out of 14 fields, and exchangeable Ca was sufficient $\left(>0.5 \mathrm{cmol}_{\mathrm{c}} \mathrm{kg}^{-1}\right)$ in all fields. The manure varied in nutrient content (Table 2). On average, $5 \mathrm{tha}^{-1}$ of manure contained $60 \mathrm{~kg} \mathrm{Nha}^{-1}, 15 \mathrm{~kg} \mathrm{Pha}^{-1}$, and $55 \mathrm{~kg} \mathrm{Kha}^{-1}$ in Kinoni and $65 \mathrm{~kg} \mathrm{Nha}^{-1}, 15 \mathrm{~kg} \mathrm{P} \mathrm{ha}^{-1}$, and $70 \mathrm{~kg} \mathrm{~K} \mathrm{ha}^{-1}$ in Muko.

\section{Yields and responses to inputs}

Application of fertilizer and/or manure significantly $(p<0.001)$ increased the grain yield (Figure $3 \mathrm{a}$ and $\mathrm{b}$ ) and stover yields (Figure $3 \mathrm{c}$ and $\mathrm{d}$ ) at both sites. However, there was large variability in yield among fields, with grain yield ranging from 0.5 to $6.0 \mathrm{tha}^{-1}$. Yields in control plots ranged from 0.5 to $3.2 \mathrm{t} \mathrm{ha}^{-1}$, while yields with NPK and/or manure ranged from 1.3 to $6.0 \mathrm{t} \mathrm{ha}^{-1}$ (Figure 4). On average grain yield was 2.8 and $4.1 \mathrm{tha}^{-1}$ for Kinoni and Muko, respectively. Average stover yield was 1.6 and $2.4 \mathrm{t} \mathrm{ha}^{-1}$ for Kinoni and Muko, respectively. Application of manure alone increased the grain yield from 1.5 to $2.8 \mathrm{tha}^{-1}$ in Kinoni (Figure $3 \mathrm{a}$ ) and from 2.6 to $4.4 \mathrm{t} \mathrm{ha}^{-1}$ in Muko (Figure 3b). In all fields, yields increased with NPK and/or manure addition. Fields in Kinoni village gave significantly $(p<0.001)$ smaller grain yield than in Muko. 
Table 1. Characteristics of the soil from the Kinoni $(n=7)$ and Muko $(n=7)$ sites

\begin{tabular}{|c|c|c|c|c|c|}
\hline \multirow[b]{2}{*}{ Soil parameters } & \multicolumn{2}{|c|}{$\begin{array}{c}\text { Kinoni } \\
\text { (low potential) }\end{array}$} & \multicolumn{2}{|c|}{$\begin{array}{c}\text { Muko } \\
\text { (high potential) }\end{array}$} & \multirow[b]{2}{*}{$p$-value } \\
\hline & Mean & Range & Mean & Range & \\
\hline $\mathrm{pH}\left(\mathrm{H}_{2} \mathrm{O}\right)$ & 6.5 & $6.3-6.7$ & 6.5 & $6.4-6.8$ & ns \\
\hline Total N $\left(\mathrm{g} \mathrm{kg}^{-1}\right)$ & 2.4 & $1.8-3.5$ & 3.1 & $2.2-4.0$ & ns \\
\hline Organic C $\left(\mathrm{g} \mathrm{kg}^{-1}\right)$ & 26.0 & $16.0-38.0$ & 34.0 & $19.0-48.0$ & ns \\
\hline Available $\mathrm{P}$ (Olsen) (mg $\mathrm{P} \mathrm{kg}^{-1}$ ) & 14.0 & $2.3-45.9$ & 32.0 & $3.0-74.1$ & ns \\
\hline Exchangeable $\mathrm{K}\left(\mathrm{cmol}_{\mathrm{c}} \mathrm{kg}^{-1}\right)$ & 0.2 & $0.1-0.6$ & 0.4 & $0.1-0.7$ & ns \\
\hline Exchangeable $\mathrm{Ca}\left(\mathrm{cmol}_{\mathrm{c}} \mathrm{kg}^{-1}\right)$ & 6.4 & $5.2-7.1$ & 6.7 & $6.0-7.3$ & ns \\
\hline Exchangeable $\mathrm{Mg}\left(\mathrm{cmol}_{\mathrm{c}} \mathrm{kg}^{-1}\right)$ & 2.1 & $1.3-2.9$ & 1.6 & $0.8-2.7$ & ns \\
\hline $\operatorname{ECEC~}\left(\mathrm{cmol}_{\mathrm{c}} \mathrm{kg}^{-1}\right)$ & 15.4 & $10.1-20.8$ & 14.0 & $9.0-18.3$ & ns \\
\hline Sand $\left(\mathrm{g} \mathrm{kg}^{-1}\right)$ & 376 & $140-688$ & 605 & $269-887$ & 0.075 \\
\hline Silt $\left(\mathrm{g} \mathrm{kg}^{-1}\right)$ & 278 & $96-433$ & 203 & $56-353$ & ns \\
\hline Clay $\left(\mathrm{g} \mathrm{kg}^{-1}\right)$ & 346 & $144-764$ & 192 & $57-358$ & ns \\
\hline
\end{tabular}

ECEC, effective cation exchange capacity.

Table 2. Characteristics of the applied manure at the Kinoni $(n=7)$ and Muko $(n=7)$ sites

\begin{tabular}{|c|c|c|c|c|}
\hline \multirow[b]{2}{*}{ Parameters } & \multicolumn{2}{|c|}{ Kinoni } & \multicolumn{2}{|c|}{ Muko } \\
\hline & Mean & Range & Mean & Range \\
\hline $\mathrm{pH}\left(\mathrm{H}_{2} \mathrm{O}\right)$ & 8.5 & $7.7-9.0$ & 8.7 & $8.2-9.6$ \\
\hline C (\%) & 15.5 & $12.0-19.3$ & 18.4 & $12.3-29.1$ \\
\hline $\mathrm{N}(\%)$ & 1.2 & $0.7-1.6$ & 1.3 & $0.6-1.9$ \\
\hline$C: N$ & 14.0 & $7.5-27.6$ & 14.9 & $9.7-23.4$ \\
\hline $\mathrm{P}(\%)$ & 0.3 & $0.1-0.5$ & 0.3 & $0.1-0.5$ \\
\hline K (\%) & 1.1 & $0.5-2.0$ & 1.4 & $0.7-4.0$ \\
\hline $\mathrm{Ca}(\%)$ & 1.1 & $0.6-1.6$ & 1.1 & $0.7-1.4$ \\
\hline Mg (\%) & 0.6 & $0.4-0.7$ & 0.6 & $0.4-1.0$ \\
\hline S (\%) & 0.1 & $0.1-0.2$ & 0.1 & $0.1-0.3$ \\
\hline B (ppm) & 37.2 & $22.7-46.0$ & 31.6 & $25.2-44.7$ \\
\hline
\end{tabular}

Application of fertilizer alone increased the grain yield from 1.5 to $2.4 \mathrm{tha}^{-1}$ in Kinoni and from 2.6 to $3.7 \mathrm{t} \mathrm{ha}^{-1}$ in Muko. Application of fertilizer together with manure increased the grain yield from 1.5 to $3.9 \mathrm{t} \mathrm{ha}^{-1}$ in Kinoni and from 2.6 to $5.4 \mathrm{t} \mathrm{ha}^{-1}$ in Muko. There was large variability in stover yield among fields, ranging from 0.4 to $4.0 \mathrm{t} \mathrm{ha}^{-1}$. Stover yield in control plots ranged from 0.4 to $2.0 \mathrm{t} \mathrm{ha}^{-1}$, while stover yield with NPK and/or manure ranged from 1.2 to $4.0 \mathrm{tha}^{-1}$. Stover yield varied greatly and the increase due to inputs application did not follow the same pattern as grain and biomass yields. On average, fertilizer and/or manure increased stover yield from 0.8 to $2.3 \mathrm{t} \mathrm{ha}^{-1}$ in Kinoni and from 1.5 to $3.4 \mathrm{t} \mathrm{ha}^{-1}$ in Muko. Biomass yield significantly $(p<0.001)$ increased with addition of fertilizer and/or manure at both sites (Figure $3 \mathrm{e}$ and $\mathrm{f}$ ). Large variability in biomass yield and response to applied inputs was also observed which followed the same pattern as grain yield at both sites.

In general, manure application led to a substantial increase in the grain yield with response of fertilizer to manure application ranging from 1.0 to $1.7 \mathrm{tha}^{-1}$ (Figure 5). Responses to inputs were smaller in Kinoni than in Muko. On average, greater response of fertilizer to manure addition was achieved when manure was used together with N or NPK fertilizers and was least with P alone, though there were no significant differences among treatments at the Kinoni site. Responses to NPK were improved by manure addition at both sites (Figure 5). There was also a weak relationship between $\mathrm{N}$ applied through manure and climbing bean grain yield response to manure application (data not shown). 
(a)

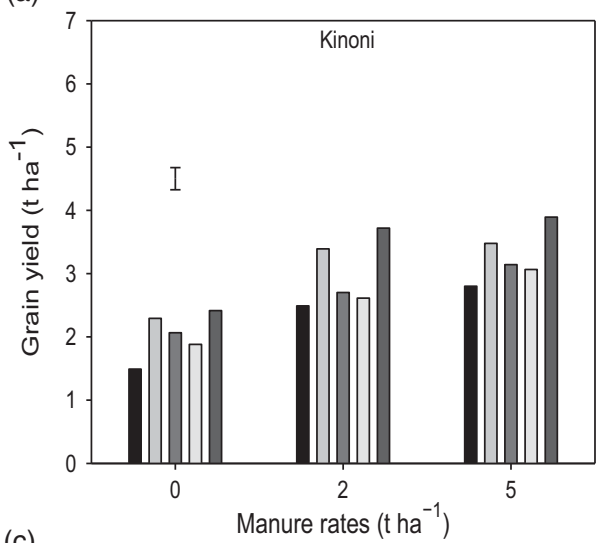

(c)

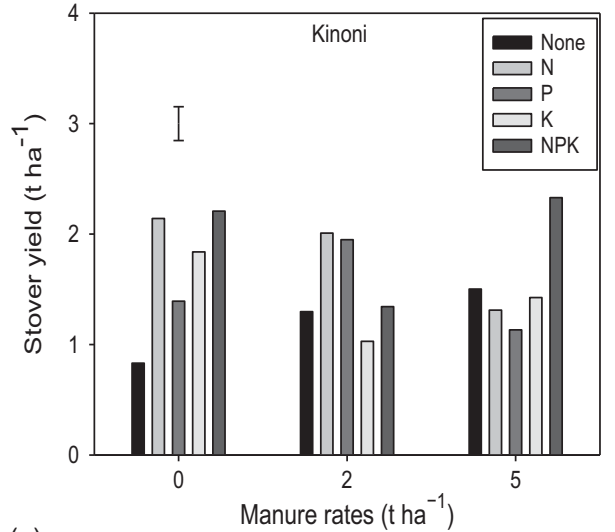

(e)

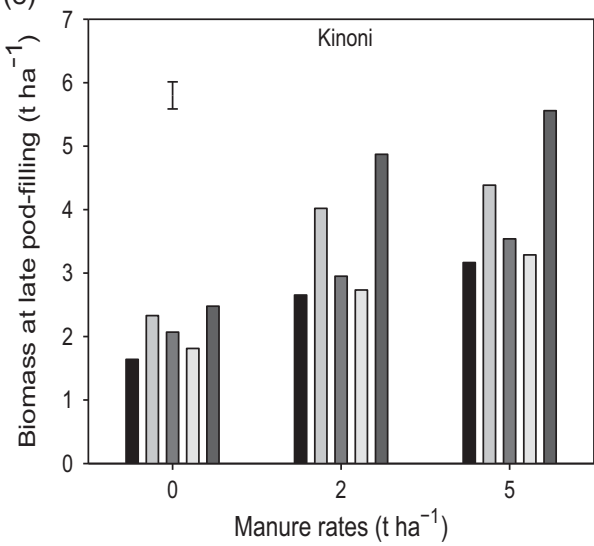

(b)

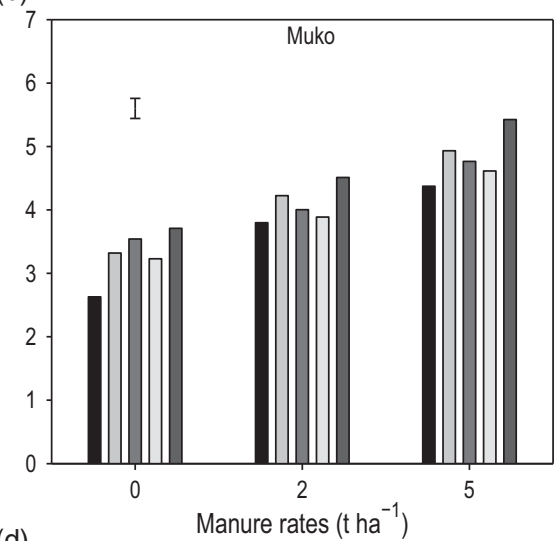

(d)

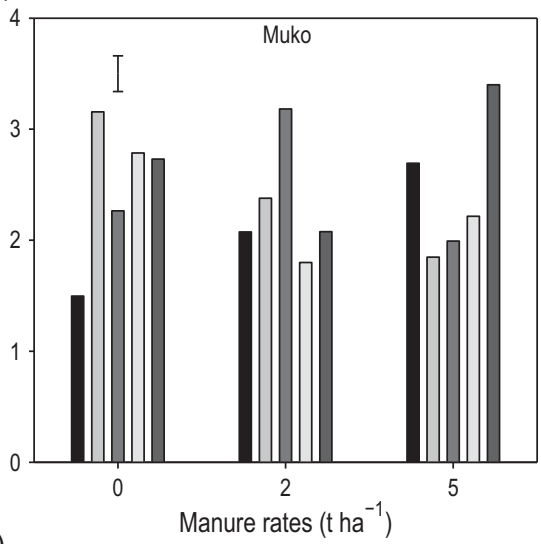

(f)

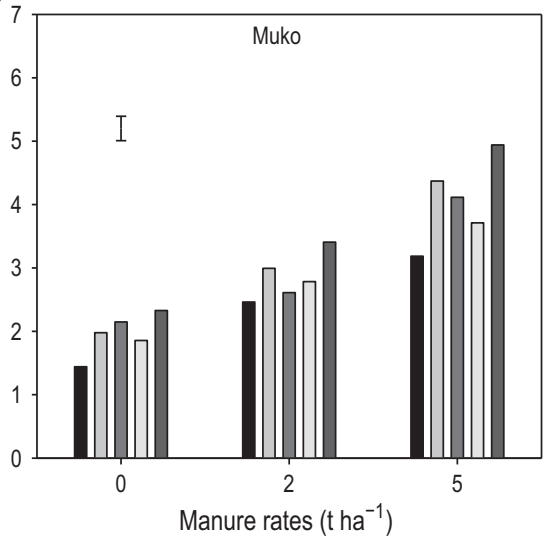

Figure 3. Climbing bean grain (a, b), stover yields (c, d), and biomass at late pod-filling (e, f) as affected by inputs at Kinoni and Muko. None: control (no fertilizer added); error bars represent the standard error of differences between treatment means.

There were interactions site $\times$ manure $\times$ fertilizer for grain yield $(p=0.019)$, biomass $(p=0.02)$, and stover $(p=0.003)$ but not for $\mathrm{N}$ and $\mathrm{P}$ uptake, $\% \mathrm{Ndfa}$, and amount of $\mathrm{N}_{2}$-fixed. The variability in yields and response to inputs observed between sites may be linked to the inherent soil fertility and differences in past management practices, though it was not assessed in this study. 

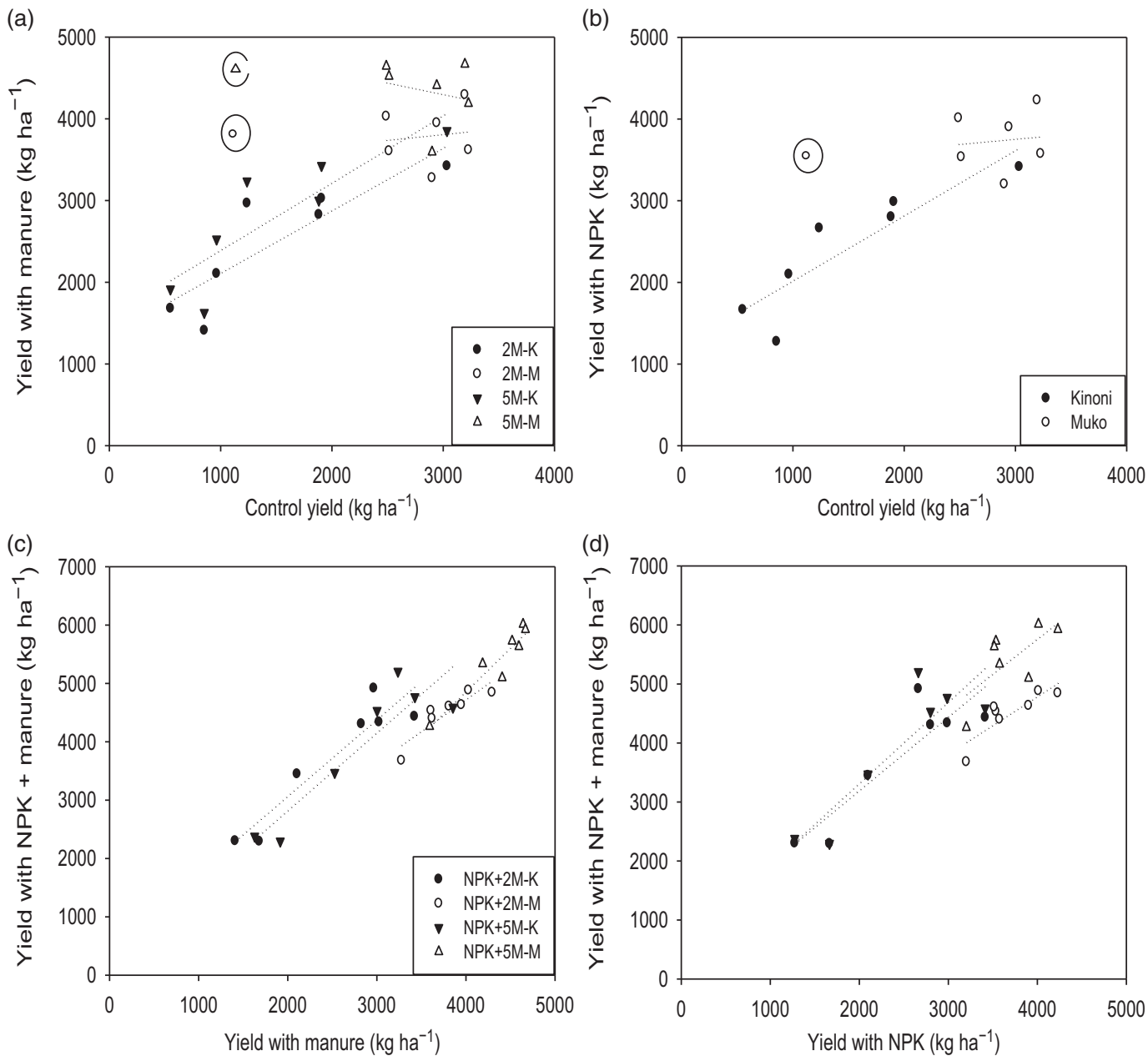

Figure 4. Climbing bean grain yield in control against (a) yield with manure $\left(\mathrm{kg} \mathrm{ha}^{-1}\right)$, (b) yield with NPK (kg ha $\left.{ }^{-1}\right)$, (c) yield with manure $\left(\mathrm{kg} \mathrm{ha}^{-1}\right)$ against yield with NPK + manure $\left(\mathrm{kg} \mathrm{ha}^{-1}\right)$, and $(\mathrm{d})$ yield with NPK $\left(\mathrm{kg} \mathrm{ha}^{-1}\right)$ against yield with NPK + manure $\left(\mathrm{kg} \mathrm{ha}^{-1}\right)$. 2M-K, $2 \mathrm{M}-\mathrm{M}, 5 \mathrm{M}-\mathrm{K}$, and $5 \mathrm{M}-\mathrm{M}$ represent 2 and $5 \mathrm{t}$ of manure ha ${ }^{-1}$ at Kinoni (K) and Muko (M) sites. The dashed lines represent linear regression lines for $(a, c, d)$ the manure rates and/or NPK and (b) NPK fertilizer at Kinoni and Muko sites. Encircled data points have been excluded from the regression analysis.

\section{$N$ and $P$ uptake and nitrogen fixation}

Shoot $\mathrm{N}$ and $\mathrm{P}$ uptake was improved by inputs application and was on average smaller in Kinoni than in Muko. In both sites, greater uptake was achieved in plots that received both fertilizer and manure, followed by plots with manure, and then plots with P fertilizer alone and was least in plots that had not received any amendment. Variability in shoot $\mathrm{N}$ and $\mathrm{P}$ uptake was observed, with shoot $\mathrm{N}$ uptake ranging from 15.1 to $176.4 \mathrm{~kg} \mathrm{~N} \mathrm{ha}^{-1}$ in Kinoni and from 15.8 to $181.1 \mathrm{~kg} \mathrm{~N} \mathrm{ha}^{-1}$ in Muko. Shoot P uptake also varied and ranged from 1.9 to $25.8 \mathrm{~kg} \mathrm{P} \mathrm{ha}^{-1}$ in Kinoni and from 1.9 to $25.4 \mathrm{~kg} \mathrm{P} \mathrm{ha}^{-1}$ in Muko. Application of inputs increased shoot $\mathrm{N}$ and $\mathrm{P}$ uptake in all fields in both sites. On average, $30 \mathrm{~kg} \mathrm{P} \mathrm{ha}^{-1}$ and $5 \mathrm{t}$ manure ha ${ }^{-1}$ applied together increased $\mathrm{N}$ uptake from 48.5 to $106.3 \mathrm{~kg} \mathrm{~N} \mathrm{ha}^{-1}$ in Kinoni and from 45.9 to $128.3 \mathrm{~kg} \mathrm{~N} \mathrm{ha}^{-1}$ in Muko. Application of $30 \mathrm{~kg} \mathrm{Pha}^{-1}$ and $5 \mathrm{t}$ manure ha ${ }^{-1}$ also increased $\mathrm{P}$ uptake from 6.1 to $12.4 \mathrm{~kg} \mathrm{P} \mathrm{ha}^{-1}$ in Kinoni 
(a)

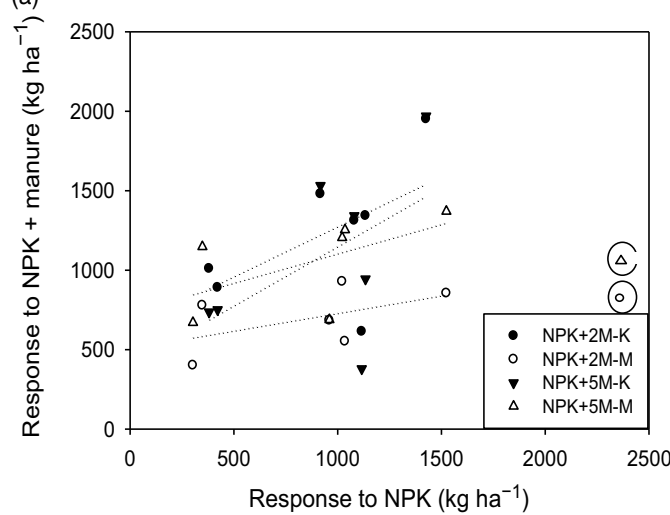

(c)

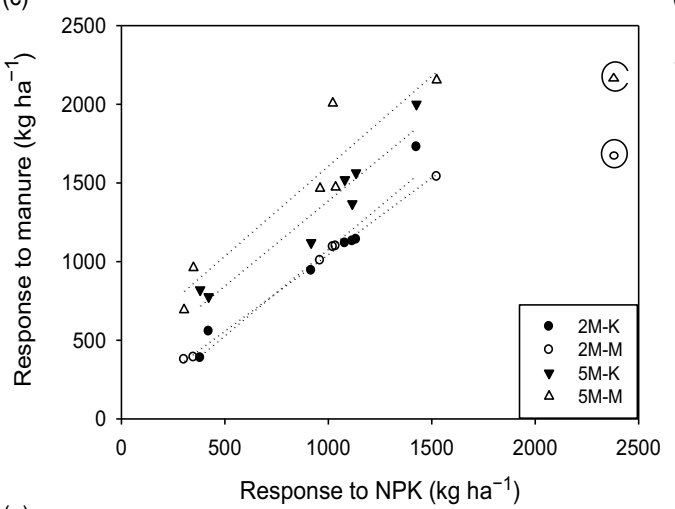

(e)

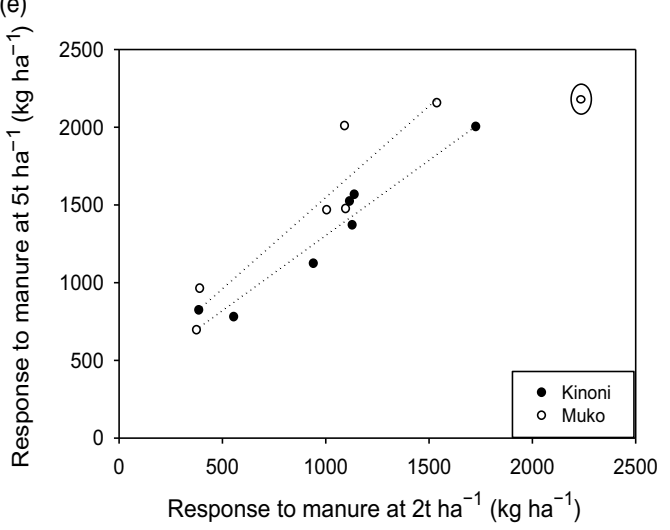

(b)

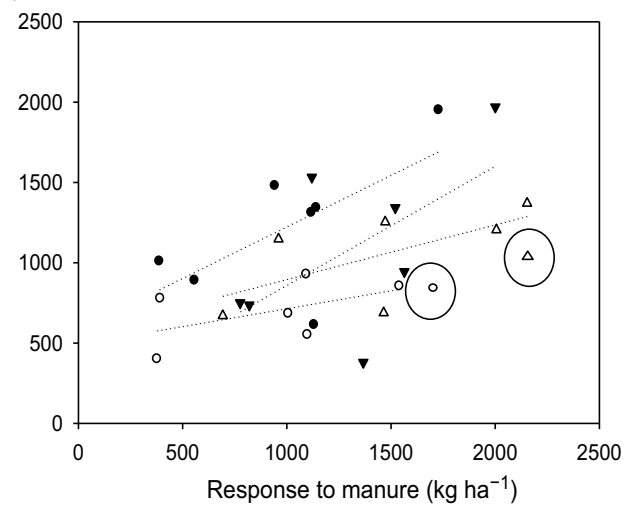

(d)

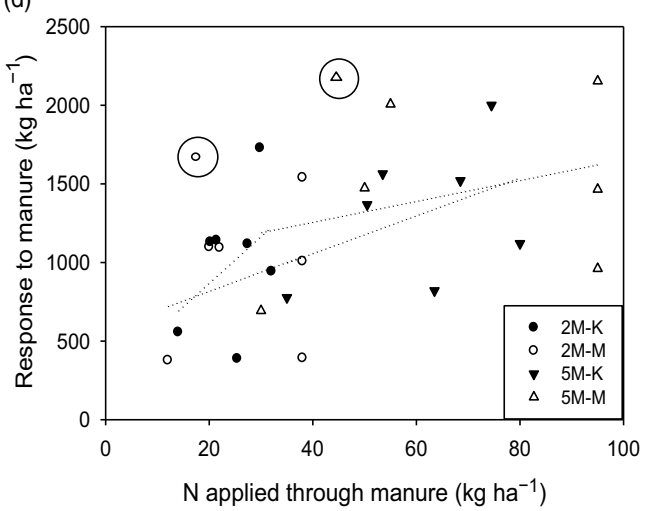

Figure 5. Relationship between (a) response to NPK (-control) against response to NPK and manure (-manure), (b) response to manure (-control) against response to NPK and manure (-manure), (c) response to NPK (-control) against response to manure (-control), (d) $\mathrm{N}$ applied through manure against response to manure (-control), and (e) response to manure at $2 \mathrm{tha}^{-1}$ against response to manure at $5 \mathrm{t} \mathrm{ha}^{-1}$ at Kinoni and Muko sites. 2M-K, 2M-M, 5M-K, and 5M-M represent 2 and $5 \mathrm{t}$ of manure ha ${ }^{-1}$ at Kinoni (K) and Muko (M) sites. The dashed lines represent the linear regression for $(\mathrm{a}, \mathrm{b}) \mathrm{NPK}$ and 2 and $5 \mathrm{t}$ manure ha ${ }^{-1}$ at Kinoni and Muko sites, and (c, d, e) 2 and $5 \mathrm{t}$ manure ha ${ }^{-1}$ at Kinoni and Muko sites. Encircled data points have been excluded from the regression analysis.

and from 5.3 to $17.9 \mathrm{~kg} \mathrm{P} \mathrm{ha}^{-1}$ in Muko (Figure 6). Increased shoot $\mathrm{N}$ and $\mathrm{P}$ uptake in treated plots than in control plots may be a result of many nutrients supply including $\mathrm{N}$ and $\mathrm{P}$, greater root system development leading to exploitation of a big volume of soil. Although $\mathrm{N}$ and $\mathrm{P}$ uptake increased with inputs application, there was no relationship between $\mathrm{N}$ applied through manure 

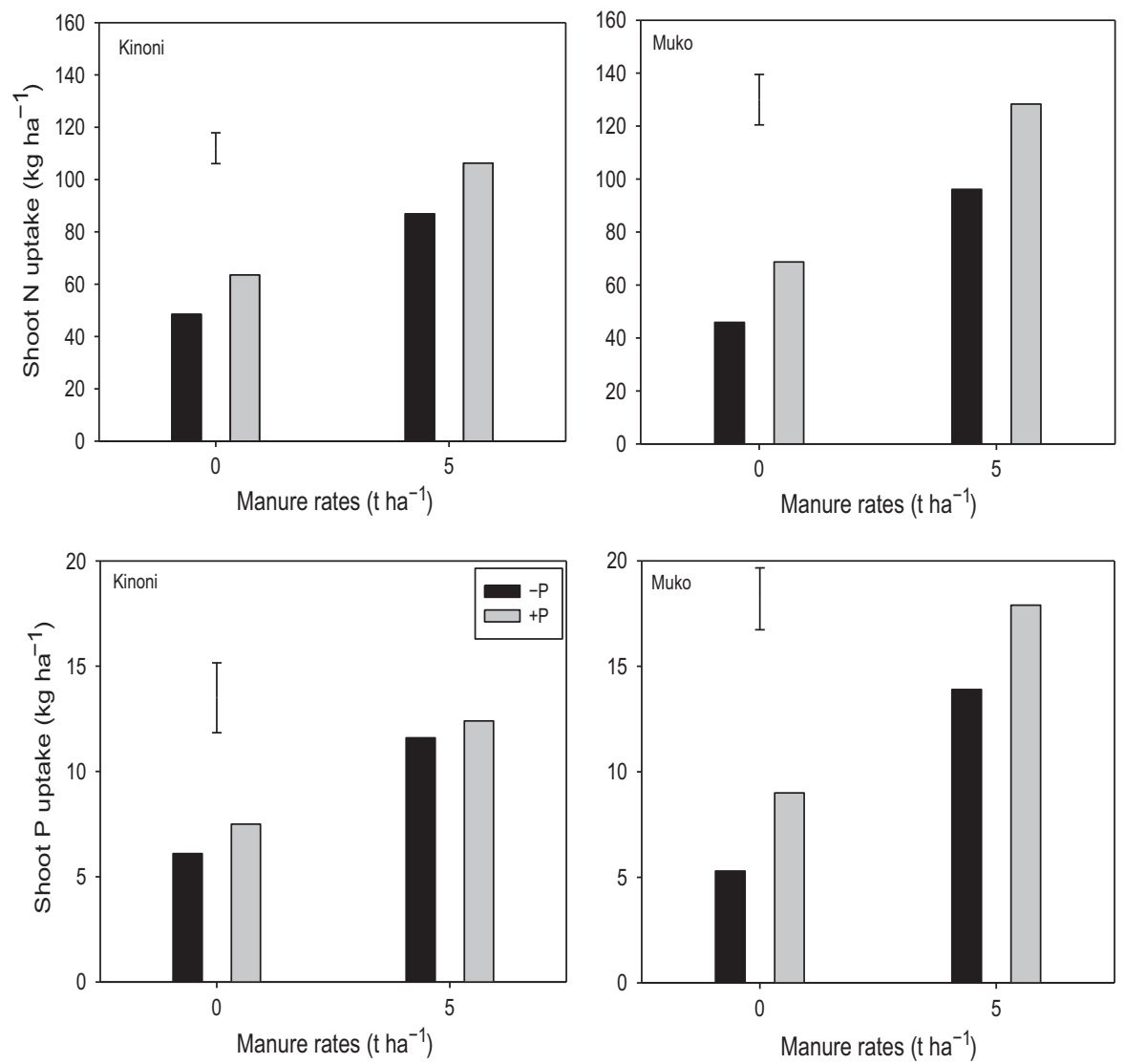

Figure 6. Shoot $\mathrm{N}$ and $\mathrm{P}$ uptake at late pod-filling as affected by treatments at Kinoni and Muko. Error bars represent the standard error of differences between treatment means.

and shoot $\mathrm{N}$ uptake and weak relationship between $\mathrm{P}$ applied through manure and shoot $\mathrm{P}$ uptake (data not shown).

Greater grain yields were observed in Muko at small amount of biomass (data not presented) and may indicate more plant growth after biomass harvest (which was done before leaves started to senesce) in Muko than in Kinoni. This high grain yield in Muko at small biomass yield may also indicate a continuous biomass production and $\mathrm{N}$ and $\mathrm{P}$ accumulation after biomass harvest at this site. This may also have led to underestimation of amount of $\mathrm{N}_{2}$-fixed in Muko as more biomass could have been produced after biomass sampling.

The \%Ndfa was on average lower in Muko (high potential) compared to Kinoni (low potential), but there was no significant difference between treatments (Table 3). No relationship was observed between biomass at late pod-filling and the $\% \mathrm{Ndfa}$ but was positively observed with the amount of $\mathrm{N}_{2}$-fixed. Positive relationships were also observed between the $\% \mathrm{Ndfa}$ and the amount of $\mathrm{N}_{2}$-fixed and between the amount of $\mathrm{N}_{2}$-fixed and biomass $\mathrm{N}$ (data not presented). The amount of $\mathrm{N}_{2}$-fixed was increased by application of fertilizer and manure and was positively influenced by the biomass $\mathrm{N}$ (data not presented). Similar positive relationships were also observed for grain yield and $\mathrm{N}$ and $\mathrm{P}$ uptake (Figure $7 \mathrm{a}$ and $\mathrm{b}$ ). The \%Ndfa slightly correlated with shoot $\mathrm{N}$ uptake, but no relationships were observed with $\mathrm{N}, \mathrm{P}$, and $\mathrm{K}$ applied through manure (data not shown). 
Table 3. Climbing bean shoot $\delta^{15} \mathrm{~N}, \delta^{15} \mathrm{~N}$ reference crop, $\% \mathrm{Ndfa}$, total $\mathrm{N}$ in shoot, and amount of $\mathrm{N}_{2}$-fixed as affected by treatments

\begin{tabular}{|c|c|c|c|c|c|c|}
\hline $\begin{array}{l}\text { Sites/fertilizer } \\
\left(\mathrm{kg} \mathrm{ha}^{-1}\right)\end{array}$ & $\begin{array}{l}\text { Manure } \\
\left(\mathrm{t} \mathrm{ha}^{-1}\right)\end{array}$ & $\begin{array}{c}\text { shoot } \delta^{15} \mathrm{~N} \\
\text { leg }(\% \circ)\end{array}$ & $\begin{array}{c}\text { Range } \\
\text { shoot } \\
\delta^{15} \mathrm{~N}(\% 0)\end{array}$ & $\% \mathrm{Ndfa}$ & $\begin{array}{l}\text { Total } N \text { in } \\
\text { shoot } \\
\left(\mathrm{kg} \mathrm{ha}^{-1}\right)\end{array}$ & $\begin{array}{c}\text { Total } \\
\text { amount } \\
\mathrm{N}_{2} \text {-fixed } \\
\left(\mathrm{kg} \mathrm{ha}^{-1}\right)\end{array}$ \\
\hline \multicolumn{7}{|l|}{ Kinoni } \\
\hline $\mathrm{OP}$ & 0 & 2.0 & -1.7 to 4.4 & 49 & 48.5 & 32.7 \\
\hline $\mathrm{OP}$ & 5 & 2.3 & $0.7-3.8$ & 42 & 89.8 & 52.1 \\
\hline $30 \mathrm{P}$ & 0 & 2.2 & $1.3-3.0$ & 42 & 63.5 & 37.0 \\
\hline $30 P$ & 5 & 2.6 & $1.0-5.9$ & 37 & 106.3 & 59.1 \\
\hline Mean/site & & 2.3 & & 43 & 77 & 45.2 \\
\hline SED (fertilizer) & & Ns & & Ns & $3.7 P=0.05$ & Ns \\
\hline SED (manure) & & Ns & & Ns & $4.4 P<0.001$ & $5.2 P<0.001$ \\
\hline \multicolumn{7}{|l|}{ Muko } \\
\hline $\mathrm{OP}$ & 0 & 3.3 & $0.9-6.3$ & 32 & 45.9 & 18.6 \\
\hline $\mathrm{OP}$ & 5 & 3.4 & $1.8-5.2$ & 30 & 96.1 & 42.2 \\
\hline $30 P$ & 0 & 3.1 & $0.9-4.2$ & 33 & 68.7 & 32.9 \\
\hline $30 P$ & 5 & 2.2 & $0.4-4.1$ & 46 & 128.3 & 79.0 \\
\hline Mean/site & & 3 & & 35 & 84.7 & 43.2 \\
\hline SED (fertilizer) & & Ns & & Ns & $3.7 P<0.001$ & Ns \\
\hline SED (manure) & & Ns & & Ns & $7.8 P<0.001$ & $8.5 P<0.001$ \\
\hline
\end{tabular}

Reference plant (maize) values: Kinoni: 5.2 (3.0-7.1) and Muko: 5.6 (4.2-7.6).

$\mathrm{Ndfa}$, percentage of $\mathrm{N}_{2}$ derived from atmosphere; leg, legume crop; ref, reference maize crop.

(a)

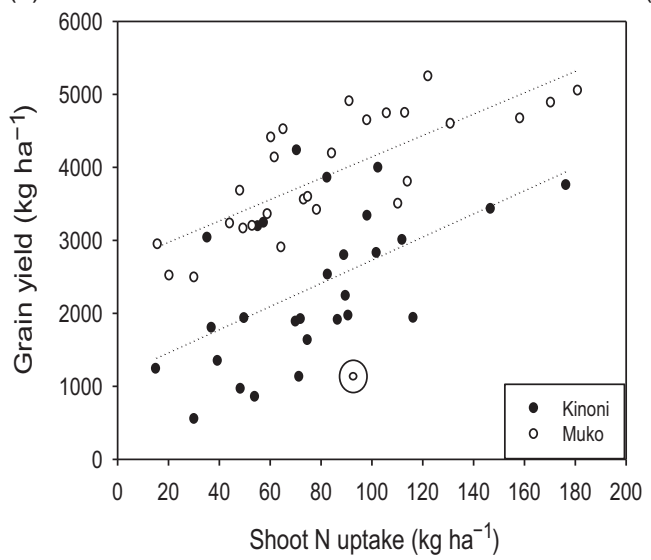

(b)

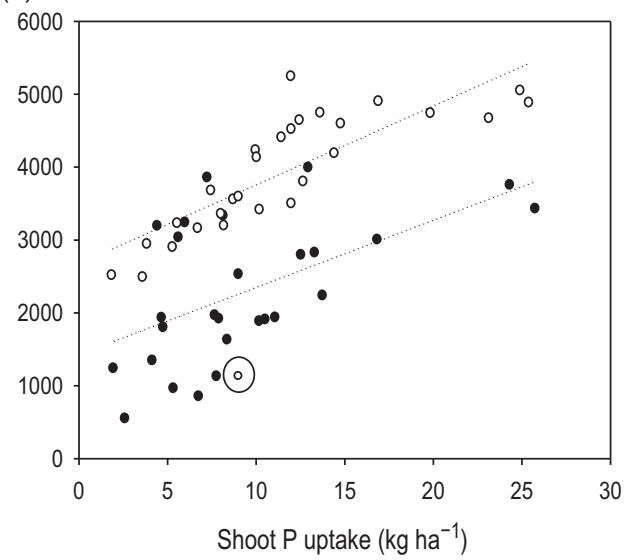

Figure 7. Climbing bean grain yield $\left(\mathrm{kg} \mathrm{ha}^{-1}\right)$ as affected by (a) shoot $\mathrm{N}$ uptake and (b) shoot $\mathrm{P}$ uptake at late pod-filling. The dashed lines represent linear relationships for Kinoni and Muko sites. The encircled data values have been excluded from the regression analysis.

\section{Soil fertility characteristics and response to applied inputs}

Responses to inputs were observed in both sites $(p<0.001)$, yet there were no clear relationships with soil parameters. In Kinoni, weak responses to manure and NPK application were observed in plots where soil available $\mathrm{P}$ and exchangeable $\mathrm{K}$ were $<10 \mathrm{mg} \mathrm{kg}^{-1}$ and $<0.2 \mathrm{cmol}_{\mathrm{c}} \mathrm{kg}^{-1}$, respectively (data not presented). However, this was not the case in Muko, suggesting that $\mathrm{P}$ and $\mathrm{K}$ were not limiting at this site. In neither of the sites, there was a clear relationship observed between soil $\mathrm{N}$ and response to inputs, suggesting that $\mathrm{N}$ was not limiting either. There were also no clear 
relationships between response to $\mathrm{P}$ and soil available $\mathrm{P}$, response to $\mathrm{N}$ and soil $\mathrm{N}$, and response to $\mathrm{K}$ and exchangeable $\mathrm{K}$ (data not shown) at both sites. In general, larger responses were observed in Muko, though there was no clear relationship with soil parameters.

\section{Discussion}

\section{Yields response to inputs and fertilizer response to manure application}

Grain, biomass, and stover yields increased with manure and fertilizer inputs at both sites. Applied individually, manure led to a greater yield increase than mineral fertilizer at both Kinoni and Muko villages. Strong increase of crop yields following manure application has been reported elsewhere. Zingore et al. (2008b) observed a substantial soybean yield increase as a result of manure application compared with yields achieved with application of single super phosphate. The strong effects of manure in increasing crop yields are attributed to its multiple functions such as supply of many nutrients including micronutrients, increasing soil organic matter contents as well as improving soil conditions needed for crop performance (De Ridder and Van Keulen, 1990; Zingore et al., 2008a, 2008b). Management options including use of manure, staking density, and height have been identified as key factors influencing climbing bean productivity (Franke et al., 2019; Musoni et al., 2014; Reckling, 2011) in Rwanda, and yield variability was strongly related to resource endowment (Franke et al., 2019). In our experiments, farmers used similar stake quality and management was the same during the study period. The differences in yields observed could be linked to differences in past management practices among the participating farmers. Increased yield of climbing bean when organic and inorganic fertilizers are combined has been reported elsewhere (Niyuhire et al., 2017). Manure is reported to increase the crop yield and responses to applied fertilizers (Rurangwa et al., 2018), and past manure application was identified as the most factor affecting yields and yields response to applied fertilizers (Njoroge et al., 2019). Surprisingly, we found no clear relationships between measured soil characteristics and climbing bean yields.

\section{$\mathrm{N}$ and $\mathrm{P}$ uptake and $\mathrm{N}_{\mathbf{2}}$-fixation}

The total $\mathrm{N}$ and $\mathrm{P}$ contents in the shoots were small in non-amended plots, and significantly increased with application of fertilizer and manure. On average, shoot $\mathrm{N}$ uptake increased from 48.5 to $128 \mathrm{~kg} \mathrm{~N} \mathrm{ha}^{-1}$ which is in the range of shoot $\mathrm{N}$ uptake reported by Ojiem et al. (2006) on various legume crops ranging from 10 to $486 \mathrm{~kg} \mathrm{~N} \mathrm{ha}^{-1}$. Increased $\mathrm{N}$ and $\mathrm{P}$ uptake may be a result of increased plant growth, hence increased plant demand. Shoot $\mathrm{N}$ uptake increased with increasing $\mathrm{N}_{2}$-fixed (Figure $7 \mathrm{~d}$ ) which was positively correlated with the biomass productivity (Figure $7 \mathrm{~b}$ ). Plant biomass has been reported to be the best predictor of nitrogen fixation (Peoples et al., 2009; Salvagiotti et al., 2008), mainly because most of the factors affecting nitrogen fixation also affect leaf photosynthesis and biomass production (Peoples et al., 2009).

The \%Ndfa varied greatly between fields ranging from 1.12 to $99.7 \%$ with a mean of $39 \%$. Observed variability in \%Ndfa is not uncommon in smallholder faming systems and has been reported extensively. Giller (2001) reviewing different papers reported high variation in \%Ndfa $(0-73 \%)$ and amount of $\mathrm{N}_{2}$-fixed $\left(2-125 \mathrm{~kg} \mathrm{~N} \mathrm{ha}^{-1}\right)$. Ojiem et al. (2006) working in Western Kenya also observed variability in \%Ndfa ranging between 7 and $90 \%$. Peoples et al. (2009) reported \%Ndfa ranging between 10 and 51\%, and Reckling (2011) observed a variation between 13 and $66 \%$. Using maize as a reference crop has been reported to underestimate the \%Ndfa (Ojiem et al., 2006). This may in part explain the small \%Ndfa observed in this study compared with the findings by Reckling (2011) in the same region. Although we could not explain the reason for the large variability in the \%Ndfa observed, environmental and management effects are reported among others to affect the \%Ndfa (Bliss, 1993). The greater grain yield achieved in 
Muko despite the relatively small amount of biomass may indicate more plant growth after biomass harvest in Muko than in Kinoni. Increased plant growth after biomass harvest may have led to an underestimation of amount of $\mathrm{N}_{2}$-fixed at this site as more biomass could have been produced after biomass sampling. Earlier studies showed that more of the plant $\mathrm{N}$ is acquired from atmosphere in the post-flowering stage compared with the earlier stages of growth (Wortmann, 2001). However, in this study, biomass was sampled at late pod-filling stage, and this shows difficulties in knowing the best time for biomass sampling in climbing bean with indeterminate growth. For this reason, there is a need for biomass sampling at different growth stages for more accurate determination of $\mathrm{N}_{2}$-fixation.

\section{Soil fertility characteristics and response to applied inputs}

Strong responses to applied inputs were observed which varied within and between the two study sites. The soils of both study sites had a wide range of nutrient contents ranging from very small to very high. However, there was no clear relationship between soil parameters and responses to applied inputs. Similarly, Franke et al. (2019) working in Northern Rwanda observed a poor correlation between soil characteristics and response to inputs. Large variability in responses was observed within and across sites, with poor yields even in some fields with good soil characteristics. This explains the lack of correlation between soil parameters and yields of climbing bean. In line with the results of this study, Franke et al. (2019) observed that organic manure application rate was positively associated with climbing bean yield. They found that greater yields were achieved in plots that received more organic manure. In this study, we also observed greater yields and yields responses in plots that received manure in combination with NPK fertilizer. Increased yields and responses when inputs are used together have been reported extensively (Ronner et al., 2016; Rurangwa et al., 2018). In Kinoni, some weak responses to manure and NPK application were observed in plots where soil available $\mathrm{P}\left(<10 \mathrm{mg} \mathrm{kg}^{-1}\right)$ and exchangeable $\mathrm{K}\left(<0.2 \mathrm{cmol}_{\mathrm{c}} \mathrm{kg}^{-1}\right)$ were limiting. However, this was not consistent as it was not seen in Muko, and it remains difficult to explain. Comparable results were reported by Franke et al. (2019) who found responses to DAP fertilizer in soil where available $\mathrm{P}$ was more limiting and with no relationship between soil $\mathrm{N}$ and response to DAP.

Although not assessed in this study, the large variability in yields observed may be linked to past management and inherent soil fertility. Variability in yields and responses to applied inputs in smallholder farmers are not uncommon. Ronner et al. (2016) working on soybean in Northern Nigeria found large variability in soybean yields and response to $\mathrm{P}+/$ or inoculation. In our study, the largest response to applied inputs was observed at Muko where the control yields were greatest, matching observations of Ronner et al. (2016) in Northern Nigeria. Similarly, Njoroge et al. (2019) working in Western Kenya observed variability in maize yield and yield responses to applied fertilizers and reported past manure application as the main factor affecting responses to applied inputs. We did not investigate the history of our field trials, but the variability in yield observed may be linked to the differences in past management practices among the participating farmers. In the study sites, many farmers rotate climbing beans with other crops such as potatoes, tomatoes, and vegetables and fertilize them with manure and/or fertilizer (Franke et al., 2019). The same source states that the amount of manure that farmers apply depends on their wealth category and the number of livestock they own.

\section{Reflections on the measurements of nitrogen fixation using maize as a reference crop}

The use of maize as a reference crop may lead to underestimation or overestimation of the \% Ndfa and its corresponding amount of $\mathrm{N}_{2}$-fixed. Many researchers have reported large variability of the $\delta^{15} \mathrm{~N}$ when maize was used as a reference crop (Chikowo et al., 2004; Ojiem et al., 2006). In our study, the $\delta^{15} \mathrm{~N}$ of the maize reference crop varied from 3.0 to $7.6(\%)$ and led to large variability 
of the \%Ndfa which ranged from 1.12 to $99.7 \%$ with a mean of $39 \%$. The total $\mathrm{N}$ harvested (total $\mathrm{N}$ in the shoot + total $\mathrm{N}$ in grain) varied widely, ranging from 52 to $382 \mathrm{~kg} \mathrm{~N} \mathrm{ha}^{-1}$ with an average of $204 \mathrm{~kg} \mathrm{~N} \mathrm{ha}^{-1}$. The total amount of $\mathrm{N}$ derived from nitrogen fixation (calculated based on the $\% \mathrm{Ndfa}$ and total $\mathrm{N}$ harvested) varied from 4 to $253 \mathrm{~kg} \mathrm{~N} \mathrm{ha}^{-1}$ with an average of $79 \mathrm{~kg} \mathrm{~N} \mathrm{ha}^{-1}$. These results lead to very low to very high $\mathrm{N}$ derived from the soil (Ndfs) ranging from 0.4 to $378 \mathrm{~kg} \mathrm{~N} \mathrm{ha}^{-1}$ with an average of $125 \mathrm{~kg} \mathrm{~N} \mathrm{ha}^{-1}$.

Considering the total soil $\mathrm{N}$ in the top soil layer $(20 \mathrm{~cm})$ plus $\mathrm{N}$ from manure applied in one ha, using a soil bulk density of $1.3 \mathrm{~g} \mathrm{~cm}^{-3}$, and by computing $\left(10,000 \times 0.2 \times 1.3 \times \mathrm{g} \mathrm{N} \mathrm{kg}^{-1}\right.$ soil)/ 1000 , where 1.3 is the soil bulk density in $\mathrm{g} \mathrm{cm}^{-3}$, and $\mathrm{g} \mathrm{N} \mathrm{kg}^{-1}$ is the measured $\mathrm{N}$ content in $1 \mathrm{~kg}$ of soil, and then all converted into $\mathrm{kg} \mathrm{N} \mathrm{ha}^{-1}$, the total $\mathrm{N}$ in the top soil layer ranges from 4680 to $10,400 \mathrm{~kg} \mathrm{~N} \mathrm{ha}^{-1}$. Assuming that $2 \%$ of the total soil $\mathrm{N}$ is mineralized in one season, an approximation which appears to have some general validity (Janssen et al., 1990), N supply from the soil obtained would vary from 94 to $1052 \mathrm{~kg} \mathrm{~N} \mathrm{ha}^{-1}$ and is higher than $20 \%$ of $\mathrm{N}$ up taken from the soil. With these assumptions, though there was large variability in observed \%Ndfa, the results obtained with the $\delta^{15} \mathrm{~N}$ estimates that suggest the climbing beans are getting $0.4-378 \mathrm{~kg} \mathrm{~N} \mathrm{ha}^{-1}$ from the soil appear to be feasible.

Similar variability in \%Ndfa, Ndfs, and total $\mathrm{N}$ harvested was observed when using broadleaved weeds as reference plants in the same region for climbing beans. In his research, Reckling (2011) used $\delta^{15} \mathrm{~N}$ of nine non $\mathrm{N}_{2}$-fixing weeds and observed \% Ndfa ranging from 11.37 to $77.97 \%$ with an average of $49 \%$, Ndfs ranging from 31 to $410 \mathrm{~kg} \mathrm{~N} \mathrm{ha}^{-1}$, and a total $\mathrm{N}$ harvested ranging from 95 to $557 \mathrm{~kg} \mathrm{~N} \mathrm{ha}^{-1}$ with an average of $182 \mathrm{~kg} \mathrm{~N} \mathrm{ha}^{-1}$.

Ojiem et al. (2007) observed variations in $\delta^{15} \mathrm{~N}$ among sites in Western Kenya for both maize and broad-leaved weeds, and maize had lower $\delta^{15} \mathrm{~N}$ values compared to broad-leaved weeds. On average, maize $\delta^{15} \mathrm{~N}$ was 3.20 and $5.89 \%$ o for broad-leaved weeds which was closer to the $8 \%{ }_{0}{ }^{15} \mathrm{~N}$ of total soil $\mathrm{N}$. These authors concluded that when maize is used as reference crop, the \% Ndfa and the corresponding $\mathrm{N}_{2}$-fixation are underestimated. The $\delta^{15} \mathrm{~N}$ of maize used as the reference crop in our study was on average $5.4 \%$ which is not far from that reported above for broad-leaved weeds in Kenya. The greater variation and small \%Ndfa observed in our study may partly be a result of the observed $\delta^{15} \mathrm{~N}$ of the legume (climbing bean) which was low to very high as well ( -1.68 to $6.31 \%$ ) compared with -0.44 to $4.10 \%$ o (Reckling, 2011 ) and -0.70 to 3.74 (Ojiem et al., 2006). With these findings, it remains uncertain which specific factors govern the $\% \mathrm{Ndfa}$ in the smallholder farming systems characterized by heterogeneous fields.

\section{Conclusion}

Application of fertilizer inputs led to greater yields in all fields of the study sites. The use of manure alongside with mineral fertilizers proved to be beneficial in increasing climbing bean yields. Greater yields were achieved when manure was used together with NPK fertilizer. Applied individually, manure seemed to be more beneficial than mineral fertilizer in increasing climbing bean yield. The use of manure and fertilizer strongly increased the uptake of $\mathrm{N}$ and $\mathrm{P}$ at both sites. Targeting the best time for biomass sampling in climbing bean for $\mathrm{N}_{2}$-fixation estimation seems to be difficult, and multiple biomass sampling at different growth stages is advised for accurate $\mathrm{N}_{2}$ fixation determination. Variability in yields and response to inputs coupled with the lack of correlation between soil characteristics and response to inputs call for a deeper understanding of the field's history/past management before fertilizer application. Looking at the large variability in \% $\mathrm{Ndfa}$ observed in this study, it remains unclear which specific factors govern the $\% \mathrm{Ndfa}$ in the smallholder farming systems. The use of a range of non- $\mathrm{N}_{2}$-fixing leguminous crops and different methods is recommended. All of the experiments reported here were conducted with the close participation of the farmers who provided their fields. These experiments, together with many demonstration plots and farmers' own tryouts, were established in major climbing bean growing 
areas over the past years (Giller and Ronner, 2019), and we have observed increasing interest in soil fertility management among the farmers as a result. The capacity to invest in fertilizer depends strongly on the ability of the farmers to invest in their production, and the Government of Rwanda has active initiatives to ensure the profitability of crop production.

Acknowledgements. We thank the Bill \& Melinda Gates Foundation for funding through a grant to Wageningen University to support the project N2Africa: Putting Nitrogen Fixation to Work for Smallholder Farmers in Africa (www.N2Africa.org). We are also grateful to the participating farmers for providing the land and their enthusiastic collaboration with the trials.

\section{References}

Bainville S., Mena R., Rasse-Mercat É. and Touzard I. (2005). La Pauvreté Des Exploitations Familiales Nicaraguayennes: Retard technique ou manque de terre? Revue Tiers Monde, Programme National Persée 183, 559-580.

Bliss F.A. (1993). Breeding common bean for improved biological nitrogen fixation. Plant and Soil 152, 71-80.

Chikowo R., Mapfumo P., Nyamugafata P. and Giller K.E. (2004). Maize productivity and mineral dynamics following different soil fertility management practices on a depleted sandy soil in Zimbabwe. Agriculture, Ecosystems and Environment 102, 119-131.

De Ridder N. and Van Keulen H. (1990). Some aspects of the role of organic matter in sustainable intensified arable farming systems in the West-African semi-arid-tropics (SAT). Nutrient Cycling in Agroecosystems 26, 299-310.

Franke A.C. and de Wolf J.J. (2011). N2Africa Baseline Report, report for the N2Africa project. 127. Wageningen: Wageningen University. http://www.n2africa.org/content/n2africa-baseline-report-0.

Franke A.C., Baijukya F., Kantengwa S., Reckling M., Vanlauwe B. and Giller K.E. (2019). Poor farmers-poor yields: Socioeconomic, soil fertility and crop management indicators affecting climbing bean productivity in Northern Rwanda. Experimental Agriculture 55, 14-34.

Franke A.C., van den Brand G.J., Vanlauwe B. and Giller K.E. (2018). Sustainable intensification through rotations with grain legumes in Sub-Saharan Africa: A review. Agriculture, Ecosystems and Environment 261, 172-185.

Giller K.E. (2001). Nitrogen Fixation in Tropical Cropping Systems, 2nd Edn. Wallingford: CAB International.

Giller K.E. and Ronner E. (2019). The Story of N2Africa: Putting Nitrogen Fixation to Work for Smallholder Farmers in Africa. Wageningen: Wageningen University and Research. Available at https://www.globalacademicpress.com/ebooks/N2/. Accessed on 10/7/2020.

Janssen B.H., Guiking F.C.T., van der Eijk D., Smaling E.M.A., Wolf J. and van Reuler H. (1990). A system for quantitative evaluation of the fertility of tropical soils (QUEFTS). Geoderma 46, 299-318.

Musoni A., Kayumba J., Butare L., Mukamuhirwa F., Murwanashyaka E., Mukankubana D., Kelly J.D., Ininda J. and Gahakwa D. (2014). Innovations to overcome staking challenges to growing climbing beans by smallholders in Rwanda. In: Vanlauwe B., Van Asten P. and G. Blomme (eds), Challenges and Opportunities for Agricultural Intensification of the Humid Highland Systems of Sub-Saharan Africa. Berlin: Springer International Publishing, pp. 129-136.

Njoroge S., Schut A.G.T., Giller K.E. and Zingore S. (2019). Learning from the soil's memory: Tailoring of fertilizer application based on past manure applications increases fertilizer use efficiency and crop productivity on Kenyan smallholder farms. European Journal of Agronomy 105, 52-61.

Nijhof K. (1987). The Concentrations of Macro-elements in Economic Products and Residues of (Sub) tropical Field Crops. Amsterdam-Wageningen: Centre for World Food Studies, p. 52.

NIS (2012). Fourth Population and Housing Census. Thematic Report: Characteristics of households and housing. Kigali: National Institute of Statistics of Rwanda.

Niyuhire M.C., Pieter Pypers P., Vanlauwe B., Nziguheba G., Roobroeck D. and Merck R. (2017). Profitability of diammonium phosphate use in bush and climbing beanmaize rotations in smallholder farms of Central Burundi. Field Crops Research 212, 52-60.

Ojiem J.O., de Ridder N., Vanlauwe B. and Giller K.E. (2006). Socio-ecological niche: a conceptual framework for integration of legumes in smallholder farming systems. International Journal of Agricultural Sustainability 4, 79-93.

Ojiem J.O., Vanlauwe B., de Ridder N. and Giller K.E. (2007). Niche-based assessment of contributions of legumes to the nitrogen economy of Western Kenya smallholder farms. Plant Soil 292, 119-135.

Okalebo J.R., Gathua K.W. and Woomer P.L. (1993). Laboratory Methods of Soil and Plant Analysis: A Working Manual. Nairobi: TSBF, 88p.

Okalebo J.R., Githua K.W. and Woomer P.L.J. (2002). Laboratory Methods of Soil and Plant Analysis: A Working Manual, 2nd Edn. Nairobi: TSBF-CIAT and SACRED Africa.

Parkinson J.A. and Allen S.E. (1975). A wet oxidation procedure suitable for the determination of nitrogen and mineral nutrients in biological material. Communications in Soil Science and Plant Analysis 6, 1-11. 
Peoples M.B., Boddey R.M. and Herridge D.F. (2002). Quantification of nitrogen fixation. In: Leigh G.J. (ed), Nitrogen Fixation at the Millennium. Amsterdam: Elsevier Science, pp. 357-389.

Peoples M., Brockwell. J., Herridge D., Rochester I., Alves B. and Urquiaga S. (2009). The contributions of nitrogen-fixing crop legumes to the productivity of agricultural systems. Symbiosis 48, 1-17. doi: 10.1007/BF03179980.

Reckling M. (2011). Characterisation of bean farming systems across farm types in northern and eastern Rwanda. Identification of potential niches for legume technologies. Plant Production Systems Group, MSc thesis, 79. Wageningen University, Wageningen.

Ronner E., Frank. A.C, Vanlauwe B., Dianda M., Edeh E., Ukem B., Bala A., van Heerwaarden J. and Giller K.E. (2016). Understanding variability in soybean yield and response to P-fertilizer and rhizobium inoculants on farmers' fields in northern Nigeria. Field Crops Research 186, 133-145.

Rugazura E. and Murugesan R. (2015). Opportunities for rural development in Musanze District, Africa: A rural livelihood analysis. International Journal of Business Management and Economic Research 6, 231-248.

Rurangwa E., Vanlauwe B. and Giller K.E. (2018). Benefits of inoculation, P fertilizer and manure on yields of common bean and soybean also increase yield of subsequent maize. Agriculture, Ecosystems and Environment 261, 219-229.

Salvagiotti F., Cassma K.G., Specht J.E., Walters D.T., Weiss A. and Dobermann A. (2008). Nitrogen uptake, fixation and response to fertilizer N in soybeans: A review. Field Crops Research 108, 1-13.

Sperling L. and Muyaneza S. (1995). Intensifying production among smallholder farmers: The impact of improved climbing beans in Rwanda. African Crop Science Journal 3, 117-125.

Stoorvogel J., Smaling E.A. and Janssen B. (1993). Calculating soil nutrient balances in Africa at different scales. Fertilizer Research 35, 227-235.

Turco R., Bischoff M., Breakwel D. and Griffith D. (1990). Contribution of soil-borne bacteria to the rotation effect in corn. Plant and Soil 122, 115-120.

Unkovich M., Herridge D., Peoples M., Cadisch G., Boddey R., Giller K.E., Alves B. and Chalk P. (2008). Measuring plantassociated nitrogen fixation in agricultural systems. Australian Centre for International Agricultural Research Monograph 136, $258 \mathrm{p}$

Vanlauwe B., Bationo A., Chianu J., Giller K.E., Merckx R., Mokwunye U., Ohiokpehai O., Pypers P., Tabo R. and Shepherd K. (2010). Integrated soil fertility management operational definition and consequences for implementation and dissemination. Outlook on Agriculture 39, 17-24.

Wortmann C.S. (2001). Nutrient dynamics in a climbing bean and sorghum crop rotation in the central Africa highlands. Nutrient Cycling in Agroecosystems 61, 267-272.

Zingore S., Delve R.J., Nyamanga J. and Giller K.E. (2008a). Multiple benefits of manure. The key to maintenance of soil fertility and restoration of depleted sandy soils on African smallholder farms. Nutrient Cycling in Agroecosystems 80, 267-282.

Zingore S., Murwira H.K., Delve R.J. and Giller K.E. (2008b). Variable grain legume yields, responses to phosphorus and rotational effects on maize across soil fertility gradients on African smallholder farms. Nutrient Cycling in Agroecosystems 80, 1-18.

Cite this article: Rurangwa E, Vanlauwe B, and Giller KE (2020). The response of climbing bean to fertilizer and organic manure in the Northern Province of Rwanda. Experimental Agriculture 56, 722-737. https://doi.org/10.1017/ S0014479720000277 